\title{
The effect of managerial overconfidence on firm value: evidence from companies listed in Tehran stock exchange
}

\author{
Mahmoud Lari Dashtbayaz ${ }^{1}$, Shaban Mohammadi ${ }^{2}$ * \\ ${ }^{I}$ Assistant Professor in Accounting, Qaenat Branch, Islamic Azad University, Qaen, Iran \\ ${ }^{2}$ Master Student in Accounting, Hakim Nezami University, Quchan, Iran \\ *Corresponding author E-mail:shaban1362@gmail.com
}

\begin{abstract}
Overconfidence, one of the most modern concepts of behavioral finance, both in financial theory and psychology is important. The effects of overconfidence managers Company's procedures, including accounting policies, hence it is important that overconfidence can be inaccurate and inappropriate policies on investment decisions, finance or accounting result and costs heavy impose on companies. Article overconfidence effect on the value of the company's review. The company's value as a dependent variable using QTobin measured. Overconfidence variable as well as the independent variable with studies based on measurement methods and their impact on the performance of 50 companies listed in Tehran Stock Exchange during 2011 to 2015 using regression analysis do. The results of this study showed that overconfidence on both methods have an impact on firm value.
\end{abstract}

Keywords: Managerial overconfidence; firm value; financial leverage; firm size.

\section{Introduction}

One of the most important factors and Management Company as concealed and non-physical factors of direct and important role in the efficient use of resources plays. Life and survival, organizational goals and increase the efficiency of the organization all the responsibilities of the management system. In a word, managing a key role in the organization. Personal preferences, tastes and feelings Administrators can select the policies and procedures affect the organization. One of the important factors that affect the behavior of managers to ensure that the problem is too much. Make more than a personal attribute that can behave as skewed and positive beliefs in relation to any aspect of the results to be defined by uncertainty. In this case, the estimate is exaggerated (Skala, 2008). Overconfidence leads to over-estimation of knowledge and skills and downplay the risks. It also leads to the feeling that you can control the issues and events, while in fact it is not. Overconfidence managers are more likely to overestimate future investment returns, hence overconfidence managers to overestimate the severity of future shocks positive cash flow of projects running led so would underestimate shocks future cash flow is negative (Ahmad \& Duellman, 2013). Overconfidence continued long-term management of their companies and their activities to reduce investment costs, is optimistic. So overconfidence lead managers are likely to underestimate the cost will be. This overconfidence management fees and sales forecast applies (Pirmoradi et al., 2013). In this case, the decision-making managers who lead by their actions and motives can affect the survival, success and failure (Pirmoradi, 2014) and in a word, performance and value of the company is the result of this study are The answer to this question is whether the overconfidence effect on the value of the company's management? And if it is applicable, the impact is positive or negative?

\section{The theoretical basis and review of litera- ture}

Overconfidence, one of the most important findings in the field of psychology of judgment and decision making. the fact of their abilities. Second, people of a certain event than it really is, see. Management plays an important role in creating value for the company. The study predicts that the value of the function of the behaviour and performance management is. Overconfidence management using over-estimates your skills and abilities, high-value estimates. The likely cause overconfidence management estimates the company's value will increase. Also, overconfidence Management is using the mechanism of overestimating the ability of their skills without comparison to others, a more accurate assessment of the increase in value of the company focuses on. In general, both managerial overconfidence behavioural mechanisms, the more likely that the increase in regarding the financial statements and there is a significant positive relationship. Check too often happens in everyday life and, consequently, the investment decision is also seen footprints. People have confidence in the correctness of their judgment more difficult and may consider the possibility of a mistake in judgment. Financial analysts after the presentation of his report so hard for his first return, even when they have more information and new information affects their previous judgment. Check too important to risk managers' personality traits that affect (Duellman \& Horowitz and Sun, 2015). Managerial overconfidence may affect the auditor's risk assessment of financial reporting because more managers' reliability, probability and impact of favourable developments on the company's cash flow more than the actual estimates and the probability and impact of negative events than the fact evaluate (Heaton, $2002 \&$ Malmendier and Tate, 2005). On the other hand a direct relationship between increased risk of distorting financial statements and management Copyright ( 2016 Mahmoud Lari Dashtbayaz, Shaban Mohammadi. This is an open access article distributed under the Creative Common Attribution License, which permits unrestricted use, distribution, and reproduction in any medium, provided the original work is properly cited. 
have confirmed high confidence and on the other hand, they have no evidence to show that the characteristics of the audited accounts for overconfidence managers linked with increased risk. If auditors become aware of managers' personality characteristics, can be expected to know the risk factors and focus on audit planning and for greater efforts to reduce detection risk, demand more rights. Therefore, the outcome can be considered as the effect and consequence of the financial reporting risk. The theoretical point of view, the higher level hypothesis (Hambrick \& Mason, 1984) states that the properties of the senior managers, decision making that affects them. One of the interesting features of management is overconfidence. Psychologists have concluded that people with high confidence, your chances of succeeding are overestimated, owes his success to his ability to understand and mainstream the role of chance and external factors in this less-than-evaluate (Wan et al., 2007). Overconfidence bias and behavioural characteristics of a person who can be a false beliefs (positive) in relation to any aspect of the event in a state of uncertainty defined, then the mean estimate will be overstated (Skala, 2008). (Chayz et al., 2014) as overconfidence in research management and tax avoidance effect of managerial overconfidence on their tax avoidance. The results of this study showed that overconfidence management puts significant positive effect on tax avoidance. Overconfidence management, cash effective tax rate increases 1.5 precent. (Chen et al., 2010) level of family and non-family corporate tax avoidance compared with each other, and came to the conclusion that family firms than domestic competitors, the less avoid paying taxes. The companies represent a unique conflict between major shareholders and wisdom is formed. Good name and reputation of the state audit and lower incentives for tax avoidance. (Schrand \& Zechman, 2011) argue, not only because of the high esteem in some situations lead to poor decision making, it will evaluate managers is a negative factor. Sometimes bad decisions or bad leaders may be optimistic, but in general, every company needs for success to the presence of people like them. (Ahmad \& Duellman, 2013) showed that overconfidence of conditional conservatism decreased and be unconditional and strong external oversight, the relationship between these two variables is not affected. (Schrand \& Zechman, 2011) stated that managers are more likely to report more reliable provider wrong due to insufficient supervision over them.

\section{Research hypotheses}

According to theoretical and empirical literature, two main hypothesis of this study is as follows:

First hypothesis: overconfidence based on EPS has an impact on firm value.

Second hypothesis: overconfidence on capital spending has an impact on firm value.

The study population was composed of companies incorporated in the Tehran Stock Exchange during the years 2011 to 2015. In this study population were adjusted on the basis of systematic characteristics, so in elections the following factors were considered: the company considered among banks, financial intermediaries, leasing and insurance companies is not (due to differences in balance and nature special activity):

- Shares are traded in all the years of the study period;

- The increase compared to the end of its fiscal year to the end of March;

- During the study, the change of the fiscal year, or does not work;

- Company Name consideration since the beginning of the study to the end of it, in the list of companies listed in the stock exchange;

- $\quad$ All data should be available from 2011 to 2015 .

The study period was from 2011 to 2015 . After examining the companies mentioned features, a total of 50 companies were selected for the sample. Research data database websites of the Stock Exchange and the NYSE were collected.

\section{Method research}

\subsection{Research variables}

Overconfidence on (COC1) EPS:

Overconfidence on the method used to calculate the difference between anticipated revenue and actual earnings per share is calculated. If the benefits are forecast to be higher than actual earnings, the number 1 that this overconfidence executive Otherwise the number 0 , so that in this case there is no overconfidence management. The yardstick to measure the managerial overconfidence in other studies, such as (Huang et al., 2011) and (Pirmoradi et al., 2013) were used.

Overconfidence on capital expenditures (COC2):

Overconfidence on the basis of this method is a dummy variable that is obtained by calculating the average cost of capital. If the cost of capital in a given year divided by total assets of more than the average level of capital expenditure is the total assets it is equal to 1 , otherwise it will get zero. The criteria for studies (Malmendier \& Tate, 2005) and (Pirmoradi et al., 2013) were used. The cost of capital for the purchase of new fixed assets or to repair and add value to existing fixed assets is entered. Purchase of land, buildings, equipment and machinery are examples of the cost of capital. The cost of capital is calculated by the formula:

Control variables:

In this study, the research background check, financial leverage and firm size variables as factors affecting the value of the company identified and were selected as control variables. Financial leverage of debt to finance assets shows. Financial leverage of total debt divided by total assets is calculated (George et al., 2008). Size of the company can demonstrate the ability to manage and the quality of accounting schemes. The natural logarithm of the book value of assets used to measure the size of the company (George et al., 2008).

Dependent variable (firm value) (PER):

In this study, based on research (King et al., 2008) Q index for measuring firm value, which is used by the total market value of equity and book value of debt divided by the book value of total assets is calculated. Variables based on the interests of managers and shareholders, which is intended to be calculated as follows:

$$
\begin{aligned}
& V A L_{i, t}=\beta_{0}+\beta_{1} \operatorname{COC1}_{i, t}+\beta_{2} \text { LEVERAGE }_{i, t}+\beta_{3} \operatorname{SIZE}_{i, t}+\varepsilon_{i, t} \\
& V A L_{i, t}=\beta_{0}+\beta_{1} \operatorname{COC2}_{i, t}+\beta_{2} \text { LEVERAGE }_{i, t}+\beta_{3} \operatorname{SIZE}_{i, t}+\varepsilon_{i, t}
\end{aligned}
$$

\section{Research results}

\begin{tabular}{|c|c|c|c|c|c|c|}
\hline $\begin{array}{l}\text { Maxi- } \\
\text { mum }\end{array}$ & $\begin{array}{l}\text { Mini- } \\
\text { mum }\end{array}$ & $\begin{array}{l}\text { Stand- } \\
\text { ard } \\
\text { devia- } \\
\text { tion }\end{array}$ & $\begin{array}{l}\text { Mid- } \\
\text { dle }\end{array}$ & $\begin{array}{l}\text { Aver- } \\
\text { age }\end{array}$ & $\begin{array}{l}\text { Num- } \\
\text { ber }\end{array}$ & Variable \\
\hline \multirow[t]{2}{*}{7.766} & 0.631 & 0.3150 & 1.315 & 1.500 & 300 & $\begin{array}{l}\text { firm } \\
\text { value }\end{array}$ \\
\hline & & & & & & \\
\hline 1 & 0 & 0.4966 & 1 & 0.6111 & 300 & $\begin{array}{l}\text { dence } \\
\text { method } \\
1\end{array}$ \\
\hline & & & & & & $\begin{array}{l}\text { Over } \\
\text { confi- }\end{array}$ \\
\hline 1 & 0 & 0.4970 & 0 & 0.4276 & 300 & $\begin{array}{l}\text { dence } \\
\text { method } \\
2\end{array}$ \\
\hline 4.59 & 0.56 & 0.5610 & 1.509 & 1.6555 & 300 & Leverage \\
\hline 7.56 & 4.89 & $\begin{array}{l}0.5032 \\
2\end{array}$ & 5.556 & 5.8987 & 300 & Size \\
\hline
\end{tabular}

Table 1: Descriptive Statistics of Variables 
Table 2: The Normal Distribution of the Variables Using the Kolmogorov-Smirnov Test

\begin{tabular}{lll}
\hline significance level & $\begin{array}{l}\text { Kolmogorov } \\
\text { Smirnov }\end{array}$ & Variable \\
\hline 0.66 & 1.28 & firm value \\
0.53 & 0.56 & Over confidence method 1 \\
0.22 & 1.03 & Over confidence method 2 \\
0.23 & 0.78 & Leverage \\
0.24 & 1.04 & Size \\
\hline
\end{tabular}

\begin{tabular}{|c|c|c|c|c|}
\hline $\begin{array}{l}\text { signifi- } \\
\text { cance level }\end{array}$ & $\begin{array}{l}\text { Adjusted } \\
\text { coefficient } \\
\text { of determi- } \\
\text { nation } \boldsymbol{R}^{2}\end{array}$ & $\begin{array}{l}\text { The coefficient } \\
\text { of determina- } \\
\text { tion } R^{2}\end{array}$ & $\begin{array}{l}\text { Multiple } \\
\text { correla- } \\
\text { tion R }\end{array}$ & $\begin{array}{l}\text { Variable } \\
\text { statistical } \\
\text { indicators }\end{array}$ \\
\hline 0.0001 & 0.069 & 0.079 & 0.288 & $\begin{array}{l}\text { Over con- } \\
\text { fidence on } \\
\text { the basis of } \\
1 \text { and } \\
\text { control } \\
\text { variables } \\
\text { with the } \\
\text { firm value }\end{array}$ \\
\hline
\end{tabular}

As Table 3 shows, using multiple regression, linear relationship between the independent variables and the dependent variables can be firm value as much as 0.288 and $0.079 \%$ of the variables are not independent of the firm value's forecast. Because of the significant 0.0001 level smaller than the significance level criterion $(0.01)$, so a significant linear relationship between the variables there with $99 \%$ confidence.

Table 4: The Results of the First Hypothesis

\begin{tabular}{|c|c|c|c|c|}
\hline $\begin{array}{l}\text { Index variance } \\
\text { inflation factor }\end{array}$ & $\begin{array}{l}\mathrm{p}- \\
\text { value }\end{array}$ & $\begin{array}{l}\text { T- } \\
\text { statistics }\end{array}$ & Constant & Variables \\
\hline \multirow{4}{*}{1.009} & 0.89 & 1.75 & 0.308 & $\begin{array}{l}\text { The remaining } \\
\text { amount }\end{array}$ \\
\hline & 0.0001 & -5.21 & -0.150 & $\begin{array}{l}\text { Over confidence } \\
\text { method } 1\end{array}$ \\
\hline & 0.112 & 1.63 & 0.04 & Leverage \\
\hline & 0.032 & 2.18 & 0.065 & Size \\
\hline 9.38 & & & & T-statistics \\
\hline 0.0001 & & & & p-value \\
\hline 1.86 & & & & Durbin - Watson \\
\hline
\end{tabular}

According to the findings in the VIF index and Watson camera can be concluded that non-linear correlation between independent variables and assumptions, there is no correlation. As can be seen in Table 4, t-variable overconfidence in Method 1 and the size of the company at the level of 0.05 is significant. So the hypothesis of the existence of a significant relationship between the level of 0.05 more certainty on the basis of EPS and value of the company was confirmed. F-Statistics and p-value indicates that the figure is significant at the level 0.0001 level. Adjusted coefficient of determination $R^{2}$ shows that the explanatory variables can explain the firm's 0.069 percent of the total value of diversity. Significant financial leverage is variable and it is no impact on firm value.

Table 5:

\begin{tabular}{lllll}
\multicolumn{1}{c}{ Table 5: } & & \\
\hline $\begin{array}{l}\text { signifi- } \\
\text { cance level }\end{array}$ & $\begin{array}{l}\text { Adjusted } \\
\text { coefficient of } \\
\text { determina- } \\
\text { tion } \\
\boldsymbol{R}^{2}\end{array}$ & $\begin{array}{l}\text { The coeffi- } \\
\text { cient of de- } \\
\text { termination } \\
\boldsymbol{R}^{2}\end{array}$ & $\begin{array}{l}\text { Multi- } \\
\text { ple } \\
\text { correla- } \\
\text { tion R }\end{array}$ & $\begin{array}{l}\text { Variable } \\
\text { statistical } \\
\text { indicators }\end{array}$ \\
\hline & & & $\begin{array}{l}\text { Over confi- } \\
\text { dence on the } \\
\text { basis of 2 } \\
\text { and control } \\
\text { variables } \\
\text { with the firm } \\
\text { value }\end{array}$ \\
\hline
\end{tabular}

As Table 5 shows, using multiple regression, linear relationship between the independent variables and the dependent variables can be firm value as much as 0.558 and $30.9 \%$ of firm value of independent variables predicted their existence. Because of the significant 0.0001 level smaller than the significance level criterion (0.01), so a significant linear relationship between the variables there with $99 \%$ confidence.

\begin{tabular}{|c|c|c|c|c|}
\hline $\begin{array}{l}\text { Index variance } \\
\text { inflation factor }\end{array}$ & $\begin{array}{l}\mathrm{p}- \\
\text { value }\end{array}$ & $\begin{array}{l}\mathrm{T}- \\
\text { statistics }\end{array}$ & Constant & Variables \\
\hline & 0.389 & -0.89 & -0.136 & $\begin{array}{l}\text { The remaining } \\
\text { amount }\end{array}$ \\
\hline 1.08 & 0.0001 & -13.68 & -0.344 & $\begin{array}{l}\text { Over confidence } \\
\text { method } 2\end{array}$ \\
\hline 1.03 & 0.0001 & 4.04 & 0.89 & Leverage \\
\hline 1.02 & 0.0001 & 5.29 & 0.133 & Size \\
\hline 49.98 & & & & T-statistics \\
\hline 0.0001 & & & & p-value \\
\hline 1.79 & & & & Durbin - Watson \\
\hline
\end{tabular}

According to the findings in the VIF index and Watson camera can be concluded that non-linear correlation between independent variables and assumptions, there is no correlation. As can be seen in Table 4, t-variable overconfidence in Method 2 and the size of the firm's level of 0.05 is significant. So at the level of 0.05 hypothesis of the existence of a significant relationship between overconfidence based on the cost of capital and the value of the company was confirmed. F-Statistics and p-value indicates that the figure is significant at the level 0.0001 level. The coefficient of determination adjusted $R^{2}$ show that the explanatory variables can explain the company's 0.305 percent of the total value of diversity.

\section{Conclusion}

This study investigated the effect of managerial overconfidence as a negative factor affecting the value of the firm. Given the theoretical basis of accounting literature, this relationship is tested in the environmental conditions of Iran. Managerial overconfidence as the independent variable based on projected benefit method and the cost of capital and a review of research conducted in this area were measured. The dependent variable is the value of the firm, using Q- Tobin was evaluated. The review of the studies on factors affecting the value of the company, financial leverage and firm size variables were selected as control variables. The hypothesis of this study using data from 50 firms listed in the Tehran Stock Exchange during the period from 2011 to 2015 was conducted. The results of hypothesis show that more negative impact on the value of the firm's safety management. It is recommended that in future studies, the comparison of managerial overconfidence in various industries, the impact of certain types of behaviour manager's overconfidence are analysed. Researchers interested can manage the relationship between overconfidence and conservatism review.

\section{Acknowledgement}

I appreciate the efforts of Mr. Ali Mohammadi valuable partner.

\section{References}

[1] Ahmed, A.S. \& Duellman, S. (2013). Managerial overconfidence and accounting conservatism. Journal of Accounting Research, 51(1): 1- 30. http://dx.doi.org/10.1111/j.1475-679X.2012.00467.x.

[2] Chyz, J., Gaertner, F., Kausar, A. \& Watson, L. (2014). Overconfidence and Aggressive Corporate Tax Policy. Available at SSRN: http://ssrn.com/ abstract=2408236.

[3] Chen, S., Chen, X., Cheng, Q. \& Shevlin, T. (2010). Are family firms more tax aggressive than non-family firms. Journal of Financial Economics, 91(1): 41-61. http://dx.doi.org/10.1016/j.jfineco.2009.02.003. 
[4] Duellman, S., Hurwitz, H. \& Sun, Y. (2015). Managerial Overconfidence and Audit Fees. Journal of Contemporary Accounting \& Economics, 11(2): 148-165. http://dx.doi.org/10.1016/j.jcae.2015.05.001.

[5] George R, Rezaul K and Qian J. (2008). Investment-Cash Flow Sensitivity and Financial Constraints: An Analysis of Indian Business Group Firms, available at SSRN.com, id = 683725 .

[6] Hambrick, D. \& Mason, P. (1984). Upper echelons: the organization as a reflection of its top managers. Academy of Management Review, 9 (2): 193-206.

[7] Heaton, J. (2002). Managerial Optimism and Corporate Finance. Financial $\quad$ Management, $31(2): \quad 33$ http://dx.doi.org/10.2307/3666221.

[8] Huang W, Jiang F, Liu Z and Zhang M. (2011). Agency Cost, Top Executives' Overconfidence, And Investment-Cashflow Sensitivity - Evidence From Listed Companies In China. Pacific Basin Finance $\begin{array}{ll}\text { Journal } & 121\end{array}$ http://dx.doi.org/10.1016/j.pacfin.2010.12.001.

[9] Huang Y, Mesak HI, Hsu MK and Qu H. (2012). Dynamic efficiency assessment of the Chinese hotel industry. Journal of Business Research 65 59-67.

[10] Kazemi S. (2011). The impact of agency costs and cash reserves on the relationship between managerial overconfidence and investment cash flow sensitivity. Accounting Master's thesis, University of Isfahan, unpublished.

[11] King M and Santor E. (2008). Family values: Ownership structure, performance and capital structure of Canadian firms, Journal of Banking and Finance 32 2423-2432. http://dx.doi.org/10.1016/j.jbankfin.2008.02.002.

[12] Liu Y and Taffler R. (2007). CEO Overconfidence in M \& A decision making and its impact on firm performance. Management School University of Edinburgh.

[13] Mahmoud Daneshvar and Kakhaki HHHSAA. (2009). the role of management in co-operatives in the village of Khorasan, Rural Development Quarterly Journal 12 23-37.

[14] Malakiankallehbasti E and Kamyabi YR. (2012). Investigating the managerial overconfidence and conservatism of the companies listed in Tehran Stock Exchange, ferdusi University of mashhad.

[15] Malmendier U and Tate G. (2005). CEO Overconfidence and Corporate Investment. Journal of Finance 6 2661-2700. http://dx.doi.org/10.1111/j.1540-6261.2005.00813.x.

[16] Pirmoradi F. (2014). Impact of managerial overconfidence on the quality of earnings of the companies listed in Tehran Stock Exchange, the thesis of Master of Science, Islamic Azad University, Science and Research of Sirjan.

[17] Pirmoradi F and Alinejadsarokaliei MA. (2013). The impact of managerial overconfidence on quality of accruals of the companies listed in Tehran Stock Exchange, second national accounting conference, financial management and investment.

[18] Presley T and Abbott L. (2013). AIA submission: CEO overconfidence and the incidence of financial restatement. Advances in Accounting, Incorporating Advances in International Accounting 29 74-84. http://dx.doi.org/10.1016/j.adiac.2013.03.007.

[19] Schrand, C.M. \& Zechman, S.L.C. (2011). Executive overconfidence and the slippery slope to financial misreporting. Journal of Accounting and Economics, 53(1-2): 311-329. http://dx.doi.org/10.1016/j.jacceco.2011.09.001.

[20] Skala D. (2008). Overconfidence is Psychology and Finance-An Interdisciplinary Literature Review 143-33-50.

[21] Wan, F., Huang, D., Lan, Q. \&Yang, X. (2007). Numerical simulation for influence of overconfidence and regret aversion on return distribution. System engineering theory \& practice, 27(7): 10-18. 